Jurnal Professional FIS UNIVED Vol. 2 No.1 Juni 2015

\title{
PENGARUH KOMUNIKASI INTERPERSONAL MAHASISWA DAN DOSEN PEMBIMBING SKRIPSI TERHADAP GEJALA STRES MAHASISWA DALAM MENYUSUN SKRIPSI
}

\author{
Oleh : \\ PUPUT CITRA YULIA, HENNY AFRIANTI, VETHY OCTAVIANI \\ Prodi Ilmu Komunikasi Fakultas Ilmu-IImu Sosial UNIVED Bengkulu
}

\begin{abstract}
This study was conducted to determine the influence of interpersonal communication between students and the thesis supervisor students in the stress symptoms thesis. Based on initial observations on Communication department students of Dehasen University year 2010, of the 62 students who have submitted a title and run the thesis counseling process, only 29 students managed to reach the stage of proposal examination. One of the obstacles faced by students is the lack of good interpersonal communication so that interpersonal relationships are not well established. This research is a quantitative descriptive. Sample set by using purposive sampling of the students of Communication Department who were working on thesis, that is 38 students. The results showed that interpersonal communication between students and thesis supervisor has not been effective so that the discussion does not go well. The ineffectiveness of communication activities lead students to experience stress symptoms so that interfere the completion of thesis writing.
\end{abstract}

\section{Keywords: Interpersonal Communication, Stress}

\section{PENDAHULUAN}

Komunikasi adalah bagian paling penting dalam aktivitas sehari-hari. Para ahli menyebutkan bahwa manusia mengalokasikan lebih dari $80 \%$ waktu mereka untuk berkomunikasi. Dengan tersampaikannya informasi, akan terbangun pemahaman dan pengertian antara dua belah pihak, khususnya bila informasi tersebut berkaitan dengan halhal penting, seperti penyelesaian perselisihan paham, cara mendidik anak, membina hubungan harmonis dalam keluarga dan kehidupan bermasyarakat, serta hal penting lainnya (Maulana \& Gumelar, 2013).

Dalam praktiknya, komunikasi yang berhasil merubah pola pikir seseorang dari yang tertutup menjadi terbuka, negatif menjadi positif, adalah komunikasi yang dibangun berdasarkan hubungan interpersonal. Tujuan komunikasi tidak akan tercapai bila komunikasi tidak berjalan efektif. Efektivitas komunikasi interpersonal tercapai bila komunikan menginterpretasikan pesan yang diterima dengan makna yang sama dari komunikator (Supraktiknya, 2010).

Komunikasi interpersonal yang efektif menyebabkan dua individu yang tergabung dalam proses komunikasi merasa senang sehingga mendorong tumbuhnya sikap saling terbuka. Sebaliknya, bila komunikasi interpersonal berjalan tidak efektif, maka menimbulkan situasi yang tegang antara pelaku komunikasi.

Komunikasi interpersonal yang memegang peranan penting dalam pembangunan sumber daya manusia namun sering disepelekan adalah komunikasi interpersonal antara mahasiswa tingkat akhir dengan dosen pembimbingnya dalam proses pembuatan skripsi. Saat mahasiswa telah menempuh semester akhir dan telah 
menyelesaikan seluruh mata kuliahnya, mahasiswa dituntut atau diwajibkan untuk membuat suatu karya ilmiah, yaitu skripsi.

Menurut Hidayat (2008) skripsi merupakan proses pembelajaran bagi mahasiswa untuk mengasah kemampuan analisisnya dalam mengkaji, menganalisis, memecahkan dan menyimpulkan masalah yang ditelitinya. Penyusunan skripsi yang diaplikasikan dalam bentuk karya ilmiah merupakan kendala terbesar yang menyebabkan mahasiswa merasa terbebani dalam menyelesaikan pendidikan akademis. Dalam penyusunan skripsi pada Universitas Dehasen ada beberapa prosedur yang harus dilalui oleh mahasiswa yaitu seperti kelengkapan administrasi, bimbingan dosen, ujian proposal dan terakhir ujian skripsi.

Berdasarkan pengamatan yang peneliti lakukan pada tanggal 5 juni 2014 terhadap mahasiswa Program Studi Ilmu Komunikasi Universitas Dehasen tahun angkatan 2010, terlihat bahwa sebagian besar mahasiswa cenderung mengalami kendala-kendala dalam menyusun skripsi, karena dari 62 mahasiswa yang mengajukan judul skripsi dan sudah menjalankan proses bimbingan skripsi hanya 29 mahasiswa yang berhasil mencapai tahap ujian seminar proposal. Kendala-kendala tersebut berupa sulitnya membagi waktu antara skripsi dan pekerjaan, sulitnya menemui dosen pembimbing, sulitnya memperoleh referensi, dan kurangnya sarana dan prasarana sehingga hambatan tersebut menambah tekanan pada mahasiswa. Selain itu, ada juga keluhan-keluhan lain yaitu, tidak adanya solusi yang pasti dari hasil koreksi yang diberikan dosen saat bimbingan. Beberapa mahasiswa bahkan mengalami stres, gangguan tidur, dan gangguan emosional sejak proses bimbingan skripsi dimulai.

Stres adalah suatu kondisi adanya tekanan fisik dan psikis akibat adanya tuntutan dalam diri dan lingkungan (Rathus \& Nevid, 2009). Pernyataan tersebut mengartikan bahwa seseorang dapat dikatakan mengalami stres ketika seseorang tersebut merasa tertekan akibat tuntutan-tuntutan dalam diri dan lingkungan. Stres tidak selalu berdampak negatif (distress) pada individu, ada juga yang berdampak positif (eustress), yang disebabkan oleh adanya perbedaan karakteristik masingmasing individu. Perbedaan karakteristik tersebut akan menentukan respon individu terhadap stimulus yang menjadi sumber stres, sehingga respon setiap individu akan berbeda walaupun stimulus yang menjadi sumber stresnya sama. Dalam konteks penyusunan skripsi, jika mahasiswa tidak bisa berkomunikasi dengan baik secara interpersonal dengan dosen pembimbingnya, bisa terjadi kesalahpahaman sehingga saran dan kritik yang diberikan dosen pembimbing tidak bisa diterima dengan baik oleh mahasiswa, begitu juga sebaliknya. Oleh sebab itu, penting bagi mahasiswa yang sedang menyusun skripsi untuk memperbaiki hubungan komunikasi interpersonal dengan dosen pembimbing agar menimbulkan kenyamanan saat bimbingan skripsi, sehingga mengurangi gejala stres. Berdasarkan fenomena di atas maka peneliti bermaksud untuk mengangkat judul "Pengaruh Komunikasi Interpersonal Mahasiswa dan Dosen Pembimbing Skripsi Terhadap Gejala Stres Mahasiswa Dalam Menyusun Skripsi" untuk mengetahui apakah komunikasi interpersonal mahasiswa dan dosen pembimbing skripsi berpengaruh terhadap gejala stres mahasiswa dalam menyusun skripsi pada Mahasiswa Program Studi Ilmu Komunikasi Fakultas Ilmu Sosial Universitas Dehasen.

\section{METODOLOGI PENELITIAN}

Tipe penelitian yang digunakan dalam penelitian ini adalah penelitian deskriptif kuantitatif. Menurut Bambang (2014), penelitian deskriptif diartikan sebagai penelitian yang dilakukan untuk memberikan gambaran yang lebih detail mengenai suatu gejala atau fenomena. Sedangkan kuantitatif adalah penyajian sebuah analisis dari fenomena yang disusun dengan data kuantitatif 
serta dapat membuat ketetapan pengukurannya dengan menggunakan teknik analisis statistik.

Kriteria pengukuran variabel dalam penelitian ini menggunakan skala Likert yaitu skala yang digunakan untuk mengukur variabel penelitian dan tingkat pengukuran ordinal yang kemudian ditabulasikan dalam pengukuran interval. Menurut Bambang (2014), ukuran ordinal adalah tersusun dari tingkatan yang paling rendah ke tingkatan paling tinggi menurut suatu atribut yang dimiliki oleh masing-masing responden lainnya. Dalam penelitian ini penulis menggunakan modifiikasi skala Likert dengan empat alternatif jawaban pada kedua variabel berdasarkan pernyataan Bambang (2014) yang menyatakan bahwa penentuan banyaknya kategori dapat disesuaikan dengan kebutuhan yang ada. Berdasarkan pernyataan tersebut penulis memilih menggunakan skala Likert dengan empat alternatif jawaban karena penulis ingin melihat kecenderungan subjek ke salah satu arah.

Tehnik penetapan sampel yang digunakan dalam penelitian ini adalah purposive sampling. Adapun karakteristik dari sampel pada penelitian ini adalah:

1. Mahasiswa Program Studi Ilmu Komunikasi Universitas Dehasen tahun akademik 2014-2015 yang sedang menyusun skripsi dengan mengajukan judul ke Fakultas Imu Sosial Program Studi Ilmu Komunikasi Universitas Dehasen Bengkulu.

2. Telah melakukan bimbingan dengan dosen pembimbing skripsi.

3. Telah melaksanakan ujian proposal.

Berdasarkan data yang peneliti peroleh dari biro Fakultas Ilmu Sosial, ada 71 mahasiswa tahun akademik 2014-2015 prodi Ilmu Komunikasi yang mengambil mata kuliah skripsi. Setelah dilakukan pembatasan berdasarkan karakteristik sampel yang disebutkan diatas, maka didapatkan sampel sebanyak 38 mahasiswa. Karena total sampel yang sangat terbatas, maka peneliti mengambil sampel penelitian ini sebanyak 38 mahasiswa yang digunakan sebagai responden penelitian.

Untuk mengumpulkan data, peneliti menggunakan beberapa teknik, yaitu: kuesioner, observasi, dan dokumentasi dari berbagai literatur seperti laporan, jurnal, buku dan publikasi ilmiah lainnya.

Penelitian ini menggunakan tehnik analisis data kuantitatif, karena data yang berwujud angka-angka (kuantitatif). Tehnik analisis data kuantitatif adalah metode yang digunakan untuk mengetahui apakah hipotesis diterima atau ditolak, selain itu penulis juga menjelaskan hubungan kausal antara variabelvariabel melalui pengujian hipotesa.

Penelitian ini meneliti ada tidaknya pengaruh komunikasi interpersonal mahasiswa dan dosen pembimbing skripsi dengan gejala stres mahasiswa dalam menyusun skripsi di Program Studi Ilmu Komunikasi Universitas Dehasen Bengkulu. Dalam penelitian ini terdapat satu variabel independent dan satu variabel dependent. Menurut Sunarto (dalam Bambang, 2014) untuk membuktikan ada tidaknya hubungan kausal variabel $\mathrm{x}$ terhadap variabel y digunakan analisis regresi linear sederhana dengan bantuan Aplikasi komputer SPSS 16 dengan taraf signifikan (alpha) yang digunakan adalah 5\%. Rumus persamaan regresi sederhana tersebut sebagai berikut :

$$
\mathrm{Y}=\mathrm{a}+\mathrm{bX}
$$

Keterangan :

Y: Subyek dalam variabel dependen yang diprediksi

a: Harga Y (gejala stres) bila X (komunikasi interpersonal) $=0$

b: Angka arah atau koefisien regresi bila $(+)$ berarti naik, bila (-) berarti menurun.

$\mathrm{X}$ : Subyek pada variabel independen yang mempunyai nilai tertentu. (Suyanto, 2008)

Pengujian keabsahan data yang digunakan dalam penelitian ini adalah dengan menggunakan tehnik Margin of Error, yaitu suatu tingkat ketidaksesuaian hasil statistik dengan kenyataan di lapangan. Margin of 
Error dapat menunjukkan keakuratan suatu penelitian/poling/survey. Sedangkan untuk menghitung titik kritis, dilakukan beberapa tahap sebagai berikut ini :

1. Hitung $(\alpha): \alpha=1-($ confidence level $/ 100)$

2. Hitung Critical Probability $(\rho): \rho=1-$ $\alpha / 2$

3. Titik kritis ditunjukkan sebagai nilai skor $\mathrm{z}$, temukan nilai skor $\mathrm{z}$ yang memiliki peluang komulatif sama dengan nilai $\rho$.

\section{HASIL PENELITIAN DAN \\ PEMBAHASAN \\ Analisis Data}

Untuk melihat adanya pengaruh komunikasi interpersonal mahasiswa dan dosen pembimbing skripsi terhadap gejala stres mahasiswa dalam menyusun skripsi pada prodi Ilmu Komunikasi Universitas Dehasen Bengkulu, data dianalisa dengan metode regresi linear taraf signifikasi 5\%.

Hasil disajikan pada tabel berikut:

Tabel 5.29 Korelasi Pengaruh Komunikasi Interpersonal Terhadap Gejala Stres Mahasiswa

\begin{tabular}{|c|c|c|c|c|}
\hline Variabel & $\mathbf{r}$ & $\begin{array}{c}\text { R } \\
\text { Square }\end{array}$ & $\begin{array}{c}\text { Persamaan } \\
\text { Regresi }\end{array}$ & P \\
\cline { 1 - 4 } $\begin{array}{c}\text { Komunikasi } \\
\text { Interpersonal }\end{array}$ & 0,665 & 0,443 & $\begin{array}{c}\mathrm{Y}=3,770 \\
-0,491 \mathrm{X}\end{array}$ & 0,000 \\
\cline { 1 - 3 } $\begin{array}{c}\text { Gejala Stres } \\
\text { Mahasiswa }\end{array}$ & & & & \\
\hline
\end{tabular}

Sumber: hasil penelitian, 2014

Dari tabel di atas dapat dilihat besarnya korelasi antara kedua variabel sebesar 0,665 , lebih besar dari nilai $r$ tabel pada jumlah sampel 38 dan taraf signifikasi 0,05 yaitu 0,320. Dengan demikian Ho ditolak dan dapat disimpulkan bahwa komunikasi interpersonal memiliki pengaruh terhadap gejala stres yang dihadapi mahasiswa. Pada tabel juga dapat dilihat nilai $\mathrm{R}$ Square sebesar 0,443 , yang berarti persamaan garis yang diperoleh dapat menerangkan 44,3\% variabel komunikasi interpersonal. Dari persamaan regresi yang diperoleh, yaitu: $\mathrm{Y}=3,770-0,491 \mathrm{X}$, dapat diprediksi setiap kenaikan 1 satuan poin komunikasi interpersonal, maka gejala stres akan menurun sebesar 0,491 poin. Apabila tidak terjadi peningkatan poin komunikasi interpersonal, maka gejala stres yang muncul hanya akan mencapai 3,770 poin.

\section{Pengujian Keabsahan Data}

Peneliti menggunakan tehnik Margin of Error untuk menguji keabsahan data penelitian dengan rumus:

Margin of error $(\mathrm{ME})=$ Titik Kritis x Standar Error

- Menentukan titik kritis :

1. Hitung $(\alpha): \alpha=1-$ (confidence level/100) $\alpha=0,05$

2. Critical Probability $(\rho)=1-$ $(\alpha / 2)=1-0,05 / 2=0,975$

3. Nilai z dari 0,995 adalah 1,96 . Jadi Nilai titik kritis data penelitian adalah 1,96.

- Menentukan Standar Error (SEx)

$\mathrm{SEx}=\mathrm{s}$ (standar deviasi) $\sqrt{ } \mathrm{n}$

Standar deviasi data berdasarkan pengolahan data melalui SPSS adalah 0,886 .

Jadi SEx $=0,886 / \sqrt{ } 38$

$$
\begin{aligned}
& =0,886 / 6,164 \\
& =0,144
\end{aligned}
$$

Jadi Nilai Margin of Error $=$ Titik Kritis x Standar Error

$$
\begin{aligned}
& =1,96 \times 0,144 \\
& =0,28
\end{aligned}
$$

Margin of Error < Titik Kritis, artinya keabsahan data dalam penelitian ini dapat diterima.

\section{Pembahasan}

Komunikasi Interpersonal Mahasiswa dan Dosen Pembimbing Skripsi

Pada hakikatnya, komunikasi interpersonal adalah komunikasi antara komunikator dengan komunikan, komunikasi antara orang-orang secara tetap muka, yang 
memungkinkan setiap pesertanya menangkap reaksi orang lain secara langsung, baik secara verbal ataupun nonverbal. Dalam konteks penelitian ini, komunikasi interpersonal terjadi antara mahasiswa dan dosen pembimbing skripsi. Dimana mahasiswa menjalankan proses bimbingan skripsi dengan dosen pembimbing skripsi secara tatap muka.

Komunikasi interpersonal mahasiswa dengan dosen pembimbing skripsi bertujuan untuk membantu mahasiswa dalam menyelesaikan permasalahan yang dihadapi saat penyusunan skripsi. Komunikasi interpersonal yang terjalin antara mahasiswa dan dosen pembimbing skripsi mempunyai peran yang sangat penting dalam membantu mahasiswa dalam membuat konsep pikir yang akan digunakan dalam penelitian. Hasil komunikasi interpersonal mahasiswa dengan dosen pembimbing skripsi juga berperan dalam pengambilan keputusan oleh mahasiswa atas masalah-masalah yang dihadapi saat menyusun skripsi.

Berdasarkan jawaban tentang komunikasi interpersonal mahasiswa dan dosen pembimbing skripsi dengan membagikan kuesioner pada Prodi Ilmu Komuniasi Universitas Dehasen Bengkulu, diketahui bahwa mahasiswa cukup mampu terbuka dalam mencerikan kendalanya kepada dosen pembimbing skripsi dan hampir sebagiannya jujur dalam mengungkapkan pendapatnya kepada dosen pembimbing skripsi, tetapi mahasiswa terkadang kurang bisa memaklumi kesibukan dosen yang sulit ditemui.

Dalam proses bimbingan tentunya dosen pembimbing skripsi memberikan masukan dan penjelesan dari skripsi yang dibuat oleh mahasiswa, dan disini mahasiswa cukup kesulitan dalam menerima hasil koreksian dosen pembimbing skripsi. Mahasiswa merasa kurang mengerti dengan penjelasan yang dosen pembing skripsi berikan, mungkin keterbatasan kemampuan mahasiswa dalam mengerjakan skripsi atau bisa jadi ketidakmampuan dalam menterjemahkan makna yang diberikan dosen pembimbing skripsi dan keterbatasan literatur yang mahasiswa miliki. Sebagai dosen yang layaknya seperti orang tua, dosen pebimbing skripsi juga memberikan motivasi kepada mahasiswa agar bersemangat dalam pengerjaan skripsi dan itu dialami hampir sebaian mahasiswa ilmu komunikasi Universitas Dehasen, tapi sebagian kecil lainnya mereasa mereka tidak diperhatikan dosen pembimbing skripsinya. Motivasi juga sangat penting sekali bagi mahasiswa yang bimbingan skripsi, mereka merasa akan lebih bersemangat dalam pengerjaan skripsi.

Dalam penelitian ini, dapat dilihat bahwa keberhasilan komunikasi interpersonal yang terjadi antara mahasiswa dan dosen pembimbing skripsi setelah disebarkanlah keusioner kepada 38 mahasiswa prodi Ilmu Komunikasi Universitas Dehasen, dari data diperoleh bahwa terdapat 1 responden $(2,6 \%)$ yang mampu berkomunikasi interpersonal dengan sangat baik, 15 responden $(39,5 \%)$ menjalin komunikasi interpersonal dengan baik, 11 responden $(28,9 \%)$ kurang dapat menjalin komunikasi interpersonal dengan baik dan 11 responden $(28,9 \%)$ lainnya sama sekali tidak dapat melakukan komunikasi interpersonal dengan baik.

Berdasarkan hasil penelitian tersebut, komunikasi interpersonal yang terjalin antara mahasiswa Prodi Ilmu Komunikasi Universitas Dehasen Bengkulu dengan dosen pembimbing skripsi kurang begitu berhasil. Komunikasi interpersonal yang berhasil dapat tercapai bila kedua belah pihak baik mahasiswa maupun dosen pembimbing skripsi mempunyai kesamaan makna dalam menginterpretasikan makna pesan yang disampaikan dalam proses komunikasi. Komunikasi interpersonal yang berhasil menyebabkan adanya perasaan sedang yang dapat mendorong adanya sikap keterbukaan kedua belah pihak, sebaliknya bila komunikasi yang terjalin tidak berjalan dengan baik maka menyebabkan timbulnya perasaan tegang yang dapat menyebabkan ketidaknyamanan pada proses bimbingan 
skripsi antara mahasiswa dengan dosen pembimbing skripsi.

Proses bimbingan skripsi belum maksimal dimanfaatkan sepenuhnya oleh mahasiswa Prodi Ilmu Komunikasi Universitas Dehasen Bengkulu, karena mahasiswa kurang bisa mengakrabkan diri dengan dosen pembimbing dalam mendiskusikan baik masalah pribadi maupun masalah skripsi dengan dosen pembimbing skripsi sehingga penundaan dalam mengerjakan skripsi yang telah dikoreksi oleh dosen pembimbing skripsi kerap terjadi yang menghambat penyelesaian skripsi tersebut.

Hal tersebut diperkuat dengan pernyataan Rahmat (2002), komunikasi dinyatakan efektif apabila pertemuan antara komunikator dengan komunikan merupakan hal yang menyenangkan. Komunikasi yang berhasil juga terlihat dari kesamaan pemahaman antara komunikator dengan komunikan. Komunikasi yang berhasil akan menghasilkan tujuan yang direncanakan.

\section{Gejala Stres Mahasiswa Dalam Penyusunan Skripsi}

Dalam penelitian ini gejala stres yang diteliti adalah gejala stres yang dialami oleh para mahasiswa tingkat akhir pada prodi Ilmu Komunikasi Universitas Dehasen Bengkulu. Sesuai dengan Sarafino, stres adalah suatu keadaan atau kondisi yang tercipta bila interaksi antara individu yang mengalami tekanan dan keadaan yang dianggap mendatangkan tekanan, membuat individu melihat adanya ketidaksepadanan, antara keadaan atau kondisi dan sistem sumber daya biologis, psikis dan sosial yang ada pada diri individu, ditandai dengan gejala gangguan fisik, gangguan emosional, gangguan kognitif dan gangguan interpersonal.

Gejala stres mahasiswa pada prodi ilmu komunikasi Universitas Dehasen cukup terlihat, dilihat dari gejala fisik mahasiswa yang mengalami gangguan tidur dan gejala psikologis seperti gangguan emosional dan gejala tingkah laku yang mempengaruhi sikap mahasiswa. Gejala stres lainnya juga ditunjukkan dengan sikap menghindar dari pergaulan mahasiswa yang lebih memilih untuk menyendiri dalam proses pengerjaan skripsi, mungkin itu dilakukan agar mahasiswa lebih fokus dalam pengerjaan skripsi.

Dari observasi yang peneliti lakukan, peneliti melihat ada beberapa mahasiswa ilmu komunikasi Universitas Dehasen yang sedikit susah mengkontrol emosinya ketika mereka mencoba menghubungi dosen pembimbing skripsinya tetapi tidak direspon, mereka juga mengeluhkan karena mereka kesulitan membagi waktu mereka itu terlihat dari hampir semua responden yang peneliti teliti berstatus sudah bekerja. Hal tersebut merupakan salah satu faktor lain yang membuat mahasiswa mengalami kecemasan yang dapat memicu gejala stres. Ada juga mahasiswa yang merasa dosen pembimbing skripsi mereka melakukan mereka dengan tidak adil, tapi setelah peneliti lihat itu dikarenakan mahasiswanya yang juga terlalu memaksakan kehendak mereka kepada dosen pembimbing skripsinya.

Untuk menemukan gejala stres yang dimaksud di atas pada mahasiswa prodi Ilmu Komunikasi Universitas Dehasen, peneliti telah menyebarkan kuesioner dan memperoleh hasil bahwa 4 responden (10,5\%) mengalami gejala stres yang sangat tinggi, 19 responden $(50,0 \%)$ masuk dalam kategori gejala stres yang tinggi, dan 15 responden $(39,5 \%)$ lainnya tidak begitu menunjukkan gejala stres (rendah).

\section{Pengaruh Komunikasi Interpersonal Mahasiswa dan Dosen Pembimbing Skripsi Terhadap Gejala Stres Mahasiswa dalam penyusunan Skripsi}

Hubungan interpersonal adalah hal penentu dalam keberhasilan komunikasi interpersonal. Seorang anak yang selalu menerima jawaban dengan respon yang baik akan merasa diperhatikan dan merasa nyaman sehingga anak tersebut memiliki tingkat kepercayaan diri yang baik. Tingkat kepercayaan diri yang baik merupakan salah 
satu indikator sikap mental yang baik. Seorang anak yang memiliki tingkat kepercayaan diri yang baik cenderung dapat mengatasi segala tekanan yang dihadapi dan lebih dapat menjalin komunikasi yang baik serta lebih mudah mengutarakan pemikirannya. Hal tersebut seperti diungkapkan Eric Berne (dalam Johana, 2012) pada teori permainan dimana orang tua adalah aspek kepribadian yang merupakan asumsi dan perilaku yang kita terima dari orang tua kita, orang dewasa adalah bagian kepribadian yang mengolah informasi secara rasional, sesuai dengan situasi dan biasanya berkenaan dengan masalahmasalah penting yang memerlukan pengambilan keputusan secara sadar, sedangkan anak adalah unsur kepribadian yang diambil dari perasaan dan pengalaman kanakkanak dan mengandung potensi ituisi, spontanitas, kreativitas dan kesenangan.

Terlihat jelas bahwa komunikasi interpersonal yang baik hanya dapat terjadi melalui hubungan interpersonal yang baik pula dan keberhasilan tersebut dapat menaikkan rasa percaya diri sehingga memperkecil gejala stres yang berupa tekanan-tekanan hidup yang dialami seseorang. Hal tersebut didukung juga dengan pernyataan Devito (dalam Herdiyan, 2013) salah satu tujuan komunikasi interpersonal adalah untuk membangun hubungan, setiap orang ingin membangun dan mempertahankan sebuah hubungan. Kita menghabiskan banyak waktu untuk melakukan komunikasi interpersonal untuk membangun dan mempertahankan hubungan sosial. Hubungan sosial menghindarkan diri kita dari kesendirian dan depresi.

Tetapi peneliti juga menemukan faktor lain dari hasil observasi yang dilakukan, gejala stres pada mahasiswa prodi Ilmu Komunikasi Universitas Dehasen juga bisa dilihat dari faktor eksternal lainnya seperti status mahasiswa yang hampir semua bekerja dan ada juga yang sudah menikah, sehingga mereka kesulitan dalam membagi waktu mereka dalam proses pengerjaan skripsi, selain itu juga kemampuan ekonomi juga bisa menjadi salah satu faktor lain yang memicu mahasiswa menunda proses pengerjaan skripsinya, dan ada juga karena tidak ada motivasi dalam diri mahasiswa itu sendiri untuk mengerjakan skripsinya. Faktor-faktor tersebutlah juga mendukung menyebabkan gejala stres pada mahasiswa Ilmu Komunikasi Universitas Dehasen Bengkulu.

Pada penelitian ini terlihat jelas bahwa terdapat pengaruh signifikan antara komunikasi interpersonal mahasiswa dan dosen pembimbing skripsi terhadap gejala stres mahasiswa pada prodi Ilmu Komunikasi Universitas Dehasen karena banyak faktor yang lain juga yang dapat menyebabkan mahasiswa mengalami gejala stres. Hal ini dapat dilihat dari nilai interpretasi koefisien korelasi (r) yaitu 0,665 yang termasuk kategori kuat.

Persamaan regresi yang didapat adalah $\mathrm{Y}=3,770-0,491 \mathrm{X}$, sehingga dapat diprediksi setiap kenaikan 1 satuan poin komunikasi interpersonal, maka gejala stres akan menurun sebesar 0,491 poin. Apabila tidak terjadi peningkatan poin komunikasi interpersonal, maka gejala stres yang muncul hanya akan mencapai 3,770 poin.

\section{PENUTUP}

\section{Kesimpulan}

Adapun kesimpulan dalam penelitian ini yaitu:

1. Pada penelitian ini dapat disimpulkan bahwa terdapat pengaruh antara komunikasi interpersonal mahasiswa dan dosen pembimbing skripsi terhadap gejala stres mahasiswa pada prodi Ilmu Komunikasi Universitas Dehasen Bengkulu, yang ditunjukkan dengan nilai interpretasi koefisien korelasi (r) yaitu 0,665 yang termasuk kategori kuat dalam hal keterbukaan, empati, sikap mendukung, sikap positif dan kesetaraan.

2. Pada observasi yang peneliti lakukan, ditemukan ada faktor lain yang dapat mempengaruhi gejala stres mahasiswa 
pada prodi Ilmu Komunikasi Universitas Dehasen Bengkulu. Adapun faktor lain tersebut adalah status pekerjaan, status pernikahan, masalah keluarga, kesulitan materi dan tidak adanya motivasi dalam diri mahasiswa tersebut untuk mengerjakan skripsi sehingga faktor lain ini juga dapat berpengaruh dan memicu gejala stres mahasiswa.

3. Komunikasi interpersonal yang baik hanya dapat terjadi melalui hubungan interpersonal yang baik pula dan keberhasilan tersebut dapat menaikkan rasa percaya diri sehingga memperkecil gejala stres yang berupa tekanan-tekanan yang dialami seseorang.

\section{Saran}

Berdasarkan penelitian mengenai pengaruh komunikasi interpersonal mahasiswa dan dosen pembimbing skripsi terhadap gejala stres pada mahasiswa prodi Ilmu Komunikasi Universitas Dehasen Bengkulu ini, peneliti memiliki saran sebagai berikut :

1. Bagi para mahasiswa diharapkan dapat mempertahankan komunikasi interpersonal yang efektif dengan dosen pembimbing skripsi dengan menjalin kedekatan dengan dosen pembimbing skripsi, membangun persepsi yang positif pada dosen pembimbing skripsi, menumbuhkan keterbukaan dan kejujuran, serta membangun kepercayaan pada dosen pembimbing skripsi karena bagaimanapun juga sikap saling pengertian, menghormati satu sama lainnya juga dapat menumbuhkan komunikasi interpersonal yang baik.

2. Berdasarkan hasil penelitian ini menyatakan bahwa ada pengaruh komunikasi interpersonal mahasiswa dan dosen pembibing skripsi terhadap gejala stres mahasiswa dalam menyusun skripsi, maka diharapkan juga dosen dapat mempertahankan komunikasi interpersonal yang efektif juga. Jika kedua belah pihak, baik mahasiswa dan dosen pembimbing skripsi dapat saling berkolaborasi secara kooperatif, dan memberikan sugesti yang baik serta semangat kepada mahasiswa maka akan sangat membantu dalam lancarnya penyusunan skripsi.

3. Bagi peneliti selanjutnya yang tertarik untuk meneliti pengaruh komunikasi interpersonal mahasiswa dan dosen pembimbing skripsi terhadap gejala stres mahasiswa dalam menyusun skripsi pada mahasiswa Program Studi Ilmu Komunikasi Fakultas Ilmu Sosial Universitas Dehasen Kota Bengkulu, agar tidak hanya meninjau dari sudut pandang mahasiswa tetapi juga dari sudut pandang dosen pembimbing skripsi. Peneliti selanjutnya juga disarankan untuk melihat faktor-faktor lainnya juga, selain itu peneliti juga menyarankan untuk memperkaya lingkup penelitian ke univeristas lainnya juga.

\section{DAFTAR PUSTAKA}

Bambang, P. \& Lina, M. (2014). "Metode Penelitian Kuantitatif”. Jakarta: PT. Raja Grafindo Persada.

Herdiyan, M. \& Gumgum, G. (2013). "Psikologi Komunikasi dan

Persuasi". Jakarta: Akademia Permata.

Nevid, J.S., Rathus, S.A. \& Greene, B. (2009). "Psikologi Abnormal, Edisi Keenam, Jilid 2”. Jakarta: Erlangga.

Prawitasari, Johana. (2012). "Psikologi Terapan, Melintas Batas Disiplin Ilmu”. Jakarta: Erlangga.

Rakhmat, Jalaluddin. (2004). "Metode Penelitian Komunikasi". Bandung: Remaja Rosdakarya. 
Jurnal Professional FIS UNIVED Vol. 2 No.1 Juni 2015

Supratiknya. (2010). "Komunikasi Antarpribadi”. Yogyakarta: Kanisius.

Suyanto, S. (2008). "Metode Penelitian Cetakan Keenam”. Yogyakarta: Mitra Cendika. 